\title{
ANALISIS STRATEGI PEMASARAN MAKANAN TRADISIONAL (STUDI KASUS INDUSTRI RENGGINANG DI KECAMATAN SAKRA PUSAT)
}

\author{
Susilawati $^{1}$, Saepul Hakkul Yakin ${ }^{2}$ \\ ${ }^{1}$ Prodi Pendidikan Ekonomi FKIP Universitas Hamzanwadi \\ email: Susi.maniezzz@yahoo.co.id \\ ${ }^{2}$ Prodi Pendidikan Ekonomi FKIP Universitas Hamzanwadi \\ email: Yakinsaiful25@gmail.com
}

\begin{abstract}
ABSTRAK
Penelitian ini bertujuan untuk menganalisis strategi pemasaran makanan tradisional (studi kasus industri rengginang di Kecamatan Sakra Pusat). Metode penelitian menggunakan metode deskriftif dengan sifat komparativ. Instrumen pengumpulan data menggunakan angket. Data angket dianalisis menggunakan matriks IFE (2,392), matriks EFE (2,739), matriks IE (2,392 dan 2,739 berada pada sel V).

Hasil analisis SWOT menghasilkan 8 alternatif strategi yang dapat dipilih oleh perusahaan yaitu: 1) Mempertahankan harga dan meningkatkan kualitas produk untuk meningkatkan kepuasan dan loyalitas konsumen. 2) Menjalin kerjasama dengan agen distributor yang potensial untuk menambah pangsa pasar. 3) Memanfaatkan lokasi yang strategis untuk menarik pelanggan yang potensial. 4) Menciptakan produk dengan bentuk dan cita rasa yang baru. 5) Mejalankan sistem manajemen organisasi internal perusahaan. 6) Membangun atau menyewa kios di tempat-tempat yang strategis untuk meningkatkan penjualan. 7) Melakukan kegiatan promosi dan iklan untuk menarik pelanggan potensial dan memperluas daerah pemasaran. 8) Membangun dan mengembangkan usaha patungan (Joint Venture) dengan pihak yang menyediakan modal dan bahan baku untuk meningkatkan kapasitas produksi.

Berdasarkan hasil analisis matrik QSPM, dari delapan alternatif strategi yang ada terdapat satu alternatif strategi yang diprioritaskan untuk dilakukan oleh perusahaan yaitu mempertahankan harga dan meningkatkan kualitas produk untuk meningkatkan kepuasan dan loyalitas konsumen dengan skor TAS sebesar 6,445.
\end{abstract}

Kata kunci: Strategi Pemasaran Makanan Tradisional

\begin{abstract}
This study aims to determine: 1). How is the implementation of a marketing strategy that has been applied by the industry rengginang players in the Sakra Center district, 2). Any internal and external factors that affect the marketing strategy at industrial rengginang in the Sakra Central District, 3). Alternative marketing strategies such as what is selected by the perpetrators of industrial enterprises rengginang in the Sakra Center district. The research method using a mix of methods.
\end{abstract}


The nature of this research is comparative to come up with new in marketing strategies rengginang in the Sakra Centre District. Data collection instruments using questionnaires. Questionnaire data were analyzed using matrix $\operatorname{IFE}(2,380)$, EFE matrix (2.943), IE matrix (0.291 and 0, 288).

SWOT analysis produced 8 alternative strategies that can be selected by the company are: 1) Maintain the price and improve product quality to increase customer satisfaction and loyalty. 2) Engaging with potential distributor agents to increase market share. 3) Utilize strategic locations to attract potential customers. 4) Create a product with the form and a new taste. 5) carry out the management system of the company's internal organization. 6) Build or rent a kiosk at strategic places to increase sales. 7) Conducting promotional activities and advertising to attract potential customers and expand the marketing area. 8) Build and develop joint ventures (Joint Venture) with those who provide capital and raw materials to increase production capacity.

The results of matrix analysis QSPM, from eight strategic alternatives that exist, there is one alternative strategy that prioritized to be done by the company is maintaining prices and improve product quality to increase customer satisfaction and loyalty with TAS score of 6.445 .

Keywords: Traditional Food Marketing Strategy

\section{PENDAHULUAN}

Indonesia merupakan negara yang memiliki kekayaan sumber daya alam yang melimpah ruah dan memiliki keanekaragaman agama, suku, budaya, begitupun dengan keanekaragaman jenis kuliner. kuliner akan menjadi sebuah corak kekayaan tersendiri bagi negara Indonesia yang tidak dimiliki oleh negara lain. Indonesia dikenal dengan lain suku lain bahasa lain pula traidisi dan jenis makanan tradisional, Indonesia pada awal kemerdekaan setiap suku memiliki identitas dengan beranekaragam jenis makanan pokonya ada yang dari beras, ubi, dan jagung. Keanekaragaman jenis kuliner ini membuat Indonesia dipandang sebagai negara yang memiliki potensi ekonomi yang bisa menjadi harga diri bangsa dan dapat menambah laju pertumbuhan ekonomi bangsa yang bersumber dari makanan tardisionalnya. Indonesia yang memiliki banyak sekali jenis makanan tradisional yang siap bersaing di pasar namun tidak bisa dikontrol dengan baik apalagi dengan masuknya beranekaragam jenis makanan modern yang siap saji, makanan tradisional seakan tidak mempunyai posisi dalam persaingan pasar. 
Konteks persaingan seperti sekarang ini seiring dengan pertumbuhan ekonomi dan perubahan lingkungan yang bgitu cepat mengharuskan setiap pelaku usaha untuk berbenah diri dengan merancang strategi serta menejmen usaha yang kuat untuk melihat setiap perubahan-prubahan atau peluang pasar terutama mereka yang tergolong dalam pelaku usaha makanan tradisional. Produksi industri makanan tardisional adalah industri kedua terbesar setelah pertanian yang memiliki salah satu pontensi prospek jangka panjang yang akan mampu menyerap tenaga kerja di daerah. Industri rumahan, memiliki pertumbuhan yang cukup pesat dibuktikan dengan semakin banyaknya rumah makan tradisional yang berinofasi menjadi makanan modern yang tersebar dari pelosok bahkan sampai dengan kotakota besar.

Fungsi usaha pada dasarnya adalah untuk memenuhi kebutuhan konsumen sekaligus untuk memenuhi keinginan konsumen demi terciptanya usaha yang sehat dan menambah pendapatan ekonomi baik rumah tangga maupun pendapatan ekonomi daerah untuk menunjang keberlangsungan hidup, selain itu untuk meningkatkan hasil usaha sesuai tujuan dan keinginan usaha yang dijalani. Untuk itu perlu memilih produksi dan strategi pemasaran serta konsep lain yang mendukung keberhasilan usaha yang dijalani demi tercapainya visi dan misi perusahaan atau usaha yang sedang dijalankan. Pemahaman tentang pasar jauh lebih penting dari pemahaman pemasaran. Karena pasar adalah tempat dimana perubahan teraktualisasi dalam wujud sikap dan perilaku konsumen dalam membeli sehingga strategi pemasaran yang efektif sangat diperlukan, stratei pemasaran yang efektif adalah yang mampu fleksibel menyesuaikan dengan perubahan pasar.

Pemasaran merupakan salah satu kegiatan pokok setiap usaha yang dijalankan untuk mempertahankan kelangsnungan hidup usahanya agar bisa terus berkembang dan bertahan untuk memperoleh laba atau untung sesuai dengan tujuan perusahaan baik usaha kecil menengah maupun perushaan besar sekalipun harus mampu menganalisis peluang pasar untuk melaksanakan strategi pemasaran produknya untuk mencapai visi dan misi perusahaan dan sesuai dengan 
perencanaan yang telah ditetapkan. Strategi pemasaran akan diperlukan untuk bisa meraih tujuan perusahaan.

Di Kecamatan Sakra Pusat yang hanya memiliki satu pasar tradisional secara otomatis semua jenis barang dan usaha ada di pasar tersebut dari makanan tradisional sampai dengan makanan siap saji yang tergolong pada makanan modern. Salah satu makanan yang bisa diamati disana adalah makanan tradisional yakni rengginang, makanan tradisional yang termasuk pada jenis makanan ringan ini masih bisa terlihat keberadaan dalam persaingan pasar meski hanya dalam pasar lokal saja. Para pelaku usaha rengginang yang ada di kecamatan Sakra masih terlihat tertatih-tatih sebagai upaya untuk meningkatkan kualitas pemasaran makanan tradisional Rengginang dan mencari strategi baru dalam memasarkan hasil produksi dan bisa bersaing dipasaran dengan produksai lainnya sehingga penulis bermaksud untuk meneliti mengenai "Analisis Setrategi Pemasaran Makanan Tradisional (Studi Kasus Pada Industri Rengginang di Kecamatan Sakra Pusat).

\section{METODE PENELITIAN}

Jenis penelitian ini adalah Studi Kasus (Case Study), menurut Depdikbud (dalam Yatim Riyanto, 2007;108) studi kasus adalah penelitian yang bertujuan untuk mempelajari seacara intensif menegani unit sosial tertentu, yang meliputi individu, kelompok, lembaga dan masyarakat. Penelitian ini menggunakan metode penelitian mix mehod menurut creswell dan Cralk (Creswell, 2008;552) adalah sebuah prosedur yang mengumpulkan, menganalisis, dan mencampurkan baik penelitian kuantitatif dan kualitatif dan metode dalam suatu studi tunggal untuk memahami masalah suatu penelitian. Sifat penelitian yang digunakan dalam penelitian ini adalah Komparartif hanya menentukan strategi yang tepat bagi perusahaan dalam menghadapi persaingan dengan menggunakan analisis faktor internal (IFE) dan eksternal (EFE), analisis SWOT dan matrik QSPM guna menentukan strategi pemasaran yang baru. 


\section{HASIL DAN PEMBAHASAN}

Pemasaran sangatlah penting dalam menjalankan usaha, pemasaran bisa dikatakan kata kunci dari setiap pelaksanaan usaha namun pemasaran juga tidak bisa berjalan lancar ketika tidak didukung oleh strategi yang jitu untuk memasarkan produksinya. Pemasaran Rengginang yang selama ini diterapkan oleh Pungasaha Renggiang adalah hanya menunggu ada pemesan yang datang untuk memesan hasil produksinya seperti yang terdapat dari wawancara saya dengan beberapa pelaku uaha Rengginang di Desa Songak Kecamatan Sakra Pusat Kabupaten Lombok Timur Iq. Fathurrahman mengungkapkan bahwa:

" Aku dit selapug dengan saq usaha renggi nga ndiq tebedui ndiq ko ketaon cara apa-apa, aku jaq mun araq jaq dengan pesen ako jaq minaq ko sesuai pira kilu i nga pesen nunga, dit endah ndiq kuah titip e iliq warung-warung. Karena mikir ko nanen nyerang ko pinaq e ora renggi kne ndaraq dengan pesen e laun kan kario-ari nga jari renggi kne”. (Senin, 26 September 2016 pukul 09.00 Wita)

Arti wawancara diatas adalah:

“ Kami tidak punya strategi apa pun yang saya tau, saya menunggu pemesan datang dulu untuk memesan hasil produksi kami dalam jumlah kiloan atau ia akan memesan berapa banyak dari hasil produksi kami, baru kami membuatnya saya tidak menitipkannya di keos-keos. Karena kalau saya buat dulu terus tidak ada yang bawa maka apa yang saya buat akan jadi sia-sia”. (Senin, 26 September 2016 pukul 09.00 Wita).

Lain lagi dari pengusaha yang lain seperti yang di ungkapkan oleh Hapsah saat wawancara ia mengatakan bahwa:

"Entan ko pasarang e ngantih ko ta pesen, dit araq senoh indah jaug e jok peken sekali 2 atau 3 jelu laguq ampuq bejaug malik jok peken nung pun ntan taq jaug paling luiq nga 25 kilu saq telu jelu nunga. (Senin, 26 September 2016 pukul 11.11 Wita).

Arti wawancara diatas adalah:

"Strategi pemasaran yag saya lakukan dengan menunggu pemesan yang akan membawa hasil pemasaran saya ke pasar saja seiap harinya dalam jumlah yang tidak banyak paling banyak hanya 25 Kg". (Senin, 26 September 2016 pukul 11.11 Wita).

\section{Analisis Lingkungan Internal dan Eksternal Perusahaan}

Analisis lingkungan internal ini diperlukan untuk mengetahui kekuatan dan kelemahan bersaing perusahaan dengan melakukan proses identifikasi terhadap berbagai faktor-faktor yang ada dalam area fungsional perusahaan. Meliputi manajemen, pemasaran, keuangan/akuntansi, produksi/operasi, penelitian dan pengembangan, dan sistem informasi manajemen. 1). Manajemen, Hal ini ditegaskan dengan hasil wawancara saya dengan Ibu Fathurrahman sebagai berikut: 
"Aku ndiq ko ketaon apah nte menejmen dit bahasa ning barug ko ngerengah, saq ketaon ko jaq pinaq rengging jari langan ko belanja saq bilang jelu nte. Ndiq ko bedui kariyawan saq tulung ako kan anak kne saq nina ning nga, separu semeton-meton kne dit menenantung kne mun kenyengka ndaraq gawiq nga. (Selasa, 27 September 2016 pukul 16.07 Wita).

Arti Wawancara diatas adalah:

"Aku tidak tahu tentang menejmen dan bahasa ini baru kami dengar, yang kami tahu hanya membuat renggiang dan sebagai jalan untuk mencukupi kebutuhan hidup kami, dan saya tidak punya kariyawan saya dibantu oleh anak perempuan saya, saudara-saudara kandung dan menantu saya". (Selasa, 27 September 2016 pukul 16.07 Wita).

2). Pemasaran, bidang penting bagi suatu usaha, karena bidang pemasaranlah yang secara langsung bersentuhan dengan konsumen. Pemasaran merupakan suatu usaha yang dilakukan perusahaan untuk mempertahankan produknya di pasaran dan memperoleh keuntungan dari penjualan produknya yang menjadi parameter berhasil tidaknya suatu usaha. Seperti yang diungkapkan oleh Ibu Hapsah dan Ibu Mahsun Zaini:

"Entan ko bejuan ngantih ko dengan rateng mesen doang atau dengan saq bedagang jok peen tiatnga mesen jari pada jaug nga jok peken, ndiq kuah saq gumana lalu bejuan atau titip e iliq warung. (Selasa, 27 September 2016 pukul 17.03)

Arti dari wawancara diatas adalah :

" Pemasaran yang saya lakukan dengan menunggu pemesan datang atau pedagang yang dipasar datang untuk memesan hasil produksi saya, saya sendiri tidak pernah menitipkan hasil produksi saya ke warung-warung atau minimarket". (Selasa, 27 September 2016 pukul 17.

Hal sedikit berbeda yang di ungkapkan Jumining ia mengatakan:

"ndiq kuah saq gumana lalu tanjaq ang e pada maraq unim o saq beketuan tiatnga, pukuq ko pinaq e amun araq dengan mesen jaq oeng kote mun ndaraq jaq titip ko te liq pisaq saq bedagang liq peken nung nga. (Sabtu, 01 Oktober 2016 pukul 09.47)

Ati wawancara diatas adalah :

"saya tidak pernah memasarkan produk saya seperti yang ditanyakan, saya hanya membuat rengginang dan ada yang pesan baru saya buat kalau pun tidak ada yang pesan saya titip di saudara saya yang buka keos di pasar terminal pancor”. (Sabtu, 01 Oktober 2016 pukul 09.47).

3). Produk, Meskipun banyak konsumen yang meminati dan membeli produk rengginang dari pengusah industri rengginang ini, tetapi sedikitnya variasi, cita rasa, dan bentuk produk rengginang yang dihasilkan menyebabkan pangsa pasar dan permintaan produk pun setagnan bahkan semakin melemah apalagi dengan banyaknya produksi rengginang yang meluai punya kemasan dan citra 
rasa yang bervariasi, sehingga menyebabkan lambannya pula perkembangan perusahaan. Saat ini para pelaku usaha industri rengginang belum memiliki varian citra rasa yang ada hanya varian ukuran saja, para pelaku industri rengginang hanya mampu menciptkan dua warna varian yakni putih dan merah ke emasan dan tiga bentuk ukuran yakni ukuran yang besar, Sedang, dan kecil. Semua produk tersebut tidak menggunakan bahan pengawet untuk menjaga kualitas produknya. Bisa disimpulkan bahwa dari segi produk para pengusaha industri rengginang belum pernah ada terobosan baru untuk membuat varian wrana, ukuran, dan rasa. 4). Harga, Harga yang ditawarkan oleh para pelaku usaha ndustri rengginang ini cukup terjangkau. Dilapangan juga terjadi variasi harga tergantung pada tingkat harga beras ketan dan tergantung pada tempat pengambilan bahan baku (beras ketan). Produk dalam kemasan $1 / 2 \mathrm{Kg}$ dijual dengan harga Rp.20.000. Untuk setiap pemesanan dalam jumlah besar pemilik memberikan diskon dalam $1 \mathrm{Kg}$ sebesar Rp.1.500-1.800 tergantung berapa banyaknya pesanan. 5). Tempat, Lokasi perusahaan yang terletak pada daerah pemukiman yang padat penduduk dan berada tepat di perbatasan antara kecamatan Selong dan Sakra yang jauh dari pasar baik pasar Sakra Pusat maupun pasar diluar Sakra Pusat, sehingga akan menyulitkan para pengusaha Rengginang untuk memasarkan produk rengginangnya kepada masyarakat dan konsumen harus menghitung biaya transportasi untuk sampai ketempat memproduksi jadi yang ada hanya konsumen sekitaran di tempat mereka memproduksi saja yakni masyarakat Songak. Dimana mayoritas pasar sasaran dari usaha ini adalah masyarakat umum. 6). Promosi, promosi yang dilakukan oleh pengusaha Rengginang sampai saat ini hanyalah dengan media mouth to mouth (Mulut-ke mulut) dari para konsumen yang sudah pernah membeli produk rengginang dari pengusaha rengginang tersebut. Kurangnya promosi yang dilakukan menyebabkan sedikit sekali masyakat di luar kecamatan Sakra Pusat yang mengetahui keberadaan produk tersebut. Dari wawancara diatas maka bisa diakatakan secara umum pengusaha Rengginang tidak pernah melakukan promosi apap pun terkait dengan produknya. 7). Keuangan/akuntansi, pencatatan keuangan merupakan salah satu cara atau seni dalam berusaha, penginflmentasian tentang pencatatan akuntasi ini bisa melihat sejauhmana perkembangan perusahaan atau usaha yang dijalankan. Siklus keuangan yang masuk dan keluar sangatlah penting dalam sebuah perusahaan karena ini akan membuat perusahaan ini menjadi sakit atau sehat.

Seperti wawancara saya dengan pengusaha Rengginang Iq. Selamin mengatakan: "ndiq tuah catet kepeng saq maung ta, saq ketaon ko bedoeng ko kepeng siq ko beli reket isiq ko pinaq renggi, ndq kuah catet kepeng saq sugun atau tama nga”. (Minggu, 02 Oktober 2016 pukul 15.30).

Arti wawancara diatas adalah : 
"Saya tidak mencatat keuanganyang saya dapatkan, yang saya tau saya punya uang untuk dipakai membeli beras ketan untuk membuat renggi, saya tjuga tidak pernah mencatat keuangan yang keluar atau masuk". (Minggu, 02 Oktober 2016 pukul 15.30),

Menurut Iq. Fathurrahman:

"ndq tuah nyatet berembi ntan atur kepeng, saq ketaon ko mun ko uah juan renggi separu tekadu e maliq minaq separu ta kadu belanja dit separu ta tabung”. (Minggu, 02 Oktober 2016 pukul 15.40)

Arti wawancara diatas adalah:

"saya dan pedagang yang lain tidak pernah mencatat kuangan, yang saya tau kalau saya sudah jual rengginang separu untuk membeli bahan baku untuk membeli lagi, separuh dipakai untuk belanja, dan separuhnya saya tabung". (Minggu, 02 Oktober 2016 pukul 15.40),

Sedangkan menurut Iq. Marzuki adalah:

"Kepeng saq maung ta berusaha nung nga nyerang ta puter e ora, ndiq tuah pikiran saq sugun tama nunga, saq rekeng ko jaq ajin reket dit ajin LPG atau kayug isig ko begoreng”. (Minggu, 02 Oktober 2016 16.30).

Arti dari wawancara diatas adalah:

"Uang yang saya dapatkan dari hasil penjualan itu hanya saya putar diusaha itu, saya tidak pernah berfikir tentang uang yang keluar masuk, yang saya hitung hanya harga pemeblian bahan baku sperti LPG atau kayu untuk menggoreng. (Minggu, 02 Oktober 2016 16.30).

8). Produksi/operasi, menjalankan usaha pasti dilihat dari bagaimana cara memproduksi bahan bakunya atau operasi diperusahaan tersebut. Memproduksi rengginang tergolong cukup mudah bisa juga dikatan sulit karena butuh satu hari untuk bisa dijual baik yang sudah kering maupun yang digoreng. Seperti wawancara saya dengan Iq. Mahsum Zaini:

"Ntan te pinaq renggi muraq, mun wah araq reket jaq jari uah renggi nyerang te krem reket, tapas di dang sampai masak, mun renggi putiq kan ndaraq campuran apa-apa reket nung nga ora wah mun renggi beaq jaq campur tote isiq gula beaq". (Senin, 03 Oktober 2016 pukul 09.00)

Arti wawancara diatas adalah:

'Cara pembuatann rengginang sangat mudah, kalau sudah ada berasketan tinggal di rendam, dikeringkan, lalu dimasukan ke panci untuk dimasak, kalau rengginang yang warna putih pembuatannya biasa saja tapi kalau yang merah maka dicampur dengan gula aren". (Senin, 03 Oktober 2016 pukul 09.00)

Seperti wawancara saya dengan Iq. Hapsah:

"Ntan taq pinaq renggi muarq nga laguq waun tekna sulit, karena sejelu ampuq nga ning wauw jari, saq geru dit saq i tegoreng. Mun mili solah 
hasilnga Maraq ntan aku pitug jam ko krem e sampai lemes, ampuk ko tapas selama 5 menit terus ko edang sampai masak. (Senin, 03 oktober 2016 pukul 10.00)

Arti wawancara diatas adalah:

"Cara membuat rengginang sangat mudah bisa juga dikatakan sulit, karena butuh satu hari produksi baru siap dipasarkan maupun yang kring dan yang sipa digoreng. Kalau mau bagus hasilnya seperti yang saya lakukan, beras ketan di rendam selama tujuh jam samapai beras ketan ini benar-benar lemas, lalu saya keangkat dan keringkan selama 5 menit dan saya masukan kedalam panci untuk dimasak". (Senin, 03 oktober 2016 pukul 10.00).

Dari hasil wawncara diatas beras ketan dikukus minimal selama 15 menit lalu sisihkan. Campurkan bumbu halus, garam, gula pasir, dan air kemudian aduk rata, kemudian rebus sampai mendidih. Tambahkan beras ketan dan aduk sampai meresap. Kukus kembali minimal selama 30 menit atau hingga matang. Angkat dan bentuk sesuai selera, lalu letakkan di atas tampah untuk dijemur. Setelah satu sisi kering, balik rengginang agar keringnya merata. Rengginang yang sudah kering kemudian digoreng dalam minyak goreng yang sudah dipanaskan di atas api sedang sampai matang. Setelah matang rengginang ditaru dikeranjang yang dilapisi karung dan diberikan koran sebagai penutup atasnya yang tidak tentu berapa berat didalam satu keranjang terkadang sampai dua samapai lima $\mathrm{Kg}$, dan juga sangat minimnya sarana dan prasarana operasional perusahaan menyebabkan produksi rengginang menjadi kurang maksimal. 9). Penelitian dan Pengembangan, pemilik selama menjalankan usaha ini tidak pernah melakukan penelitian dan pengembangan terhadap produknya baik dari segi rasa, bentuk, dan kemasannya. Selama ini pemilik hanya selalu menjaga kualitas baik dari segi bentuk maupun rasa produknya agar tetap sesuai dengan keinginan konsumen dan produk yang dihasilkan dapat bertahan lama tanpa menggunakan bahan pengawet. 10). Sistem Informasi Manajemen, alat informasi yang selama ini digunakan oleh pengusaha Rengginang adalah hanya dengan konsumen datang lansung memesan dalam jumlah $\mathrm{Kg}$. Ada juga menggunakan via telpon melalui hand phone ini digunakan untuk menunjang kegiatan pemasaran produknya dalam melakukan transaksi jual beli dengan konsumen. 
Pelaku Usaha Rengginang di Kecamatan Sakra Pusat Kabupaten Lombok Timur

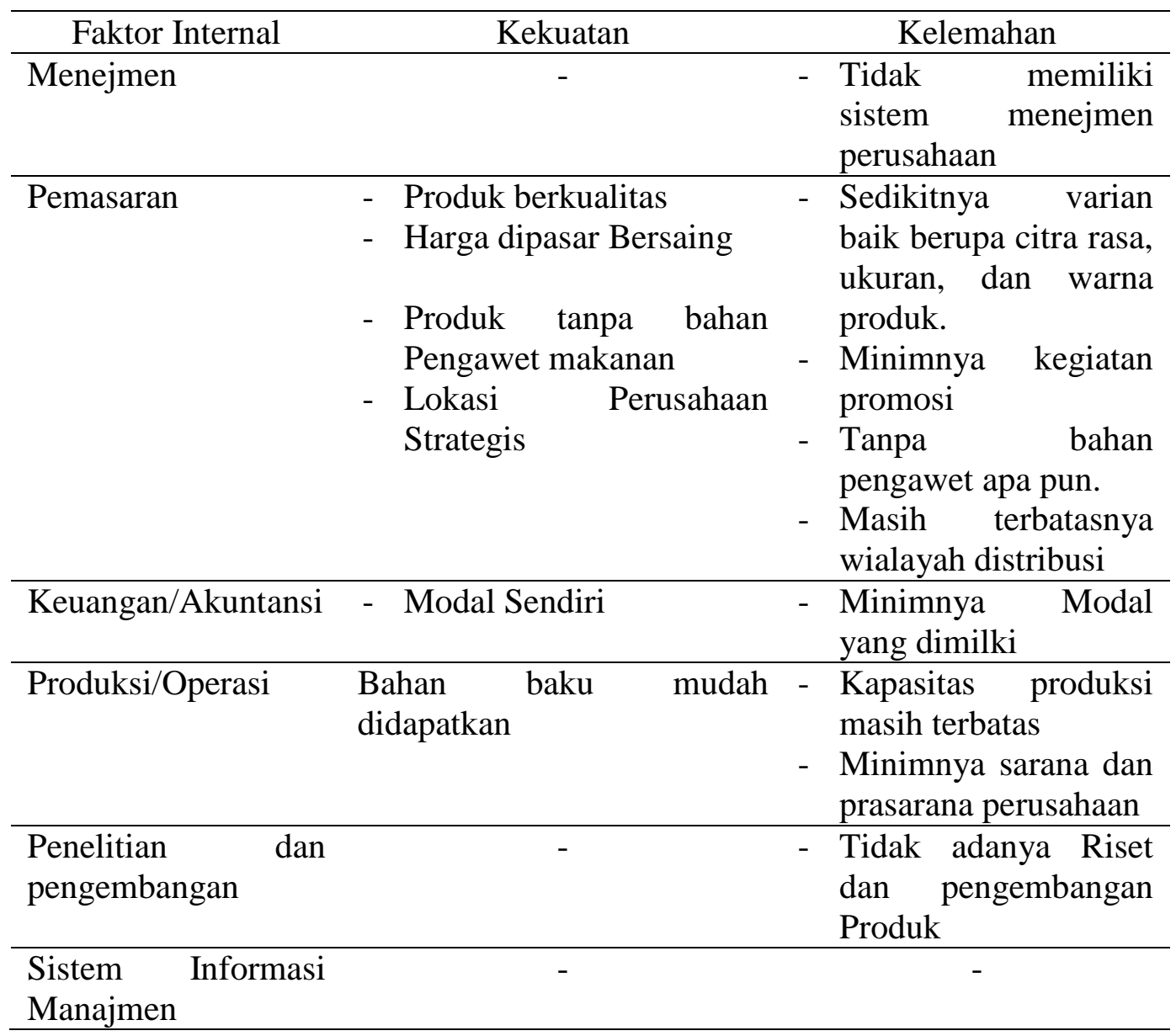

Sumber : Data Primer diolah tahun 2016

\section{Analisis Lingkungan Eksternal Perusahaan}

Analisis lingkungan internal bertujuan untuk mengembangkan sebuah daftar terbatas dari peluang yang dapat menguntungkan sebuah perusahaan dan ancaman yang harus dihindarinya. Meliputi lingkungan makro (faktor demografi, ekonomi, alam, politik, dan budaya), lingkungan mikro (pemasok, perantara pemasaran, pelanggan, pesaing, dan masyarakat), dan lingkungan industri (ancaman pendatang baru, ancaman barang substitusi/pengganti, kekuatan tawarmenawar pemasok, kekuatan tawar menawar pembeli, dan Persaingan Dari Perusahaan Sejenis Dalam Industri:

1). Lingkungan Makro, lingkungan makro meliputi: a). Faktor Demografi, Bertambahnya jumlah populasi penduduk di Indonesia dan semakin tingginya tingkat pendidikan masyarakat dunia adalah merupakan salah satu 
kekuatan yang terus dipantau oleh para pemasar, karena pasar dan karakteristiknya dibentuk secara langsung oleh masyarakat. b). Faktor Ekonomi, keadaan perekonomian suatu negara akan mempengaruhi kinerja suatu perusahaan atau industri di dalam negara tersebut. c). Faktor Alam, Bagi para pengusaha Industri Rengginang faktor alam adalah faktor yang sangat penting dan memiliki pengaruh yang besar terhadap kuantitas, kualitas, tingkat penjualan, dan keuntungan yang diperoleh dari hasil produksi rengginangnya. Proses produksi rengginang yang membutuhkan cuaca panas untuk melakukan penjemuran untuk mengeringkan rengginang tersebut adalah salah satu proses produksi terpenting dalam pembuatan rengginang. d). Faktor Teknologi, teknologi merupakan salah satu fungsi yang memegang peran penting dalam perkembangan suatu industri. Perkembangan teknologi yang semakin pesat menuntut kalangan industri untuk berusaha mengamati bahkan mengadopsi perkembangan dari berbagai teknologi yang ada saat ini untuk menunjang seluruh kegiatan operasional usahanya. e). Faktor Politik, keadaan politik di suatu negara baik secara langsung maupun tidak langsung memiliki pengaruh yang besar bagi kelangsungan hidup suatu usaha. Pemantauaan perlu dilakukan secara terus menerus oleh perusahaan baik mengenai situasi politik, Peraturan-peraturan dan kebijakan-kebijakan pemerintah baik pemerintah pusat/daerah, terutama kebijakan mengenai UMKM dapat mempengaruhi perkembangan usaha industri rengginang ini. F). Faktor Budaya, berkembangnya zaman dan Pertumbuhan jumlah penduduk telah banyak merubah jiwa sosial, budaya masyarakat, dan pola hidup masyarakat saat ini. Bagi para pengusaha industri rengginang, pertumbuhan jumlah penduduk adalah merupakan sebuah peluang, karena akan mempengaruhi jumlah konsumsi dan permintaan masyarakat terhadap produknya.

2). Lingkungan Mikro, pada lingkungan mikro ada beberapa hal yaitu: a). Pemasok, bahan baku utama pembuatan renggginang dari pengusaha industri rengginang ini adalah beras ketan. Beras ketan diperoleh oleh pemilik dengan membelinya langsung ke toko-toko sembako yang ada di pasar daerah Kalibaru, begitu juga dengan bahan-bahan pendukung lainnya termasuk kemasan produk di beli di pasar tersebut. b). Perantara Pemasaran, selain memasarkan produk 
rengginangnya secara langsung kepada konsumen, pemilik juga memasarkannya melalui perantara pemasaran. Perantara pemasaran yang digunakan saat ini adalah toko-toko ataupun minimarket yang ada di dalam pasar daerah Sakra Pusat, Pasar Terminal Pancor dan toko-toko lain yang ada di lingkungan kecamatan Sakra Pusat. c). Pelanggan, pelanggan yang dimiliki oleh para pengusaha industri rengginang saat ini terbagi menjadi dua pasar yaitu pasar konsumen dan pasar penjual perantara. d). Pesaing, pesaing utama dari para pengusaha industri rengginang ini bukanlah perusahaan yang memproduksi produk yang sejenis, meskipun dilingkungan kecamatan Sakra Pusat sendiri banyak produk sejenis dari unit usaha lain yang dipasarkan. e). Masyarakat, melihat pola hidup masyarakat sekarang yang sudah modern adalah merupakan suatu tantangan dan kesulitan tersendiri bagi para pengusaha industri rengginang untuk mengembangkan usahanya yang bergerak dalam bidang ritel makanan tradisional.

3). Lingkungan Industri, lingkungan industri meliputi: a). ancaman pendatang baru, daya tarik suatu industri bagi pesaing baru tergantung pada tingginya hambatan masuk dan keluar, serta pada reaksi dari peserta persaingan yang sudah ada menurut perkiraan calon pendatang baru. Munculnya pendatang baru dalam industri makanan tradisional rengginang dapat menjadi suatu ancaman bagi para pengusaha industri rengginang terhadap pangsa pasar yang dimiliki. b). Ancaman barang substitusi/pengganti, Industri Rengginang sebagai sebuah industri yang memproduksi produk makanan tentunya sangat rawan dan memiliki banyak sekali barang substitusinya dikarenakan semakin beragamnya produk makanan yang ada saat ini baik makanan tradisional maupun makanan modern. Meskipun karakteristik dari makanan berbeda-beda tetapi pada dasarnya memiliki fungsi yang sama antara satu dengan yang lainnya. c). kekuatan tawar menawar pemasok, Pemasok dapat memanfaatkan kekuatan tawar menawarnya atas pembeli dengan menaikkan harga atau menurunkan kualitas dan kuantitas barang atau jasa yang dijualnya. Pemasok cenderung menjadi kuat jika jumlah mereka sedikit, tetapi dengan sedikit produk yang dipasok merupakan kekuatan tawar yang penting bagi pemasok. d). Kekuatan tawar menawar pembeli, Produk rengginang dari para pengusaha industri rengginang sudah banyak dikenal dan 
diminati oleh masyarakat dari media promosi mouth to mouth yang dilakukan oleh orang-orang yang telah membeli produk tersebut. Banyak konsumen yang berkata kalau rengginang yang dihasilkan rasanya lebih gurih dan kualitasnya lebih baik dibandingkan dengan produk rengginang lainnya. Hal ini menyebabkan kekuatan tawar menawar pembeli sangat kecil. e). Persaingan dari perusahaan sejenis dalam industri, Persaingan dalam industri akan mempengaruhi kebijakan dan kinerja dari industri. Persaingan antar sesama produsen rengginang sangat berpengaruh terhadap kelangsungan hidup perusahaan.

Tabel 2

Rumusan peluang dan ancaman Industri Rengginang di Kecamatan Sakra Pusat

\begin{tabular}{|c|c|c|}
\hline Faktor Ekternal & Peluang & Ancaman \\
\hline $\begin{array}{l}\text { Lingkungan } \\
\text { Makro }\end{array}$ & $\begin{array}{l}\text { - Bertambahnya populasi } \\
\text { penduduk } \\
\text { - Perkembangan dunia } \\
\text { internet }\end{array}$ & $\begin{array}{l}\text { - Kenaikan harga bahan bakar } \\
\text { minyak } \\
\text { - Dibukanya pasar bebas pada } \\
\text { tahun } 2015 \\
\text { - Perubahan Cuaca yang tidak } \\
\text { stabil } \\
\text { - Fluktuasi nilai tukar rupiah } \\
\text { - Pola hidup masyarakat yang } \\
\text { sudah modern } \\
\end{array}$ \\
\hline $\begin{array}{l}\text { Lingkungan } \\
\text { Mikro }\end{array}$ & $\begin{array}{l}\text { - Ketersediaan bahan baku } \\
\text { yang melimpah } \\
\text { - Banyaknya agen distributor } \\
\text { - Tingginya loyalitas } \\
\text { kosumen terhadap produk } \\
\text { perusahaan } \\
\text { - Pangsa pasar masih luas } \\
\text { - Perkembangan industri } \\
\text { wisata } \\
\end{array}$ & $\begin{array}{l}\text { - Banyaknya produsen ritel } \\
\text { makanan modern }\end{array}$ \\
\hline $\begin{array}{l}\text { Lingkungan } \\
\text { Industri }\end{array}$ & - & - Banyaknya produk substitusi \\
\hline
\end{tabular}

Sumber: Data Primer diolah tahun 2016

\section{Analisis dan idetifikasi Faktor Internal dan Eksternal}

Melihat dari faktor Internal dan eksternal maka dapat dievaluasi bahwa Pemasaran yang dilakukan oleh para pengusaha industri rengginang saat ini yaitu dengan cara pemasaran langsung dan tidak langsung. Pemasaran langsung dilakukan dengan cara konsumen dapat datang langsung ke rumah tempat para pengusaha memproduksi rengginang. hasil analisisnya sebagai berikut: 
1). Matrik IFE (Internal Factor Evaluation), analisis matrik IFE merupakan hasil dari identifikasi faktor internal berupa kekuatan (strengths) dan kelemahan (weakness) yang berpengaruh terhadap industri rengginang. Penentuan nilai dan bobot dengan menggunakan metode paired comparison. Pada tabel 3.8 dapat dilihat bahwa berdasarkan hasil perhitungan dengan menggunakan matrik IFE diperoleh total skor yang dimiliki para pengusaha industri rengginang sebesar 2,392. Skor bobot total yang berada di bawah 2,5, mengindikasikan bahwa lemahnya posisi internal perusahaan dalam mengatasi kelemahan yang ada dengan kekuatan yang dimilikinya. Hasil dari tabel 3.8 menunjukkan bahwa kekuatan utama perusahaan adalah produk yang berkualitas tanpa baan pengawet (skor 0,177), karena produk yang dihasilkan memiliki kualitas yang lebih baik di bandingkan para pesaingnya baik dari segi ketahanan produk dan cita rasa yang dapat memberikan kepuasan tersendiri bagi konsumen dan membuat konsumen tersebut memiliki loyalitas yang sangat tinggi terhadap produk perusahaan.

2). Matrik EFE (External Factor Evaluation), Analisis matrik IFE merupakan hasil dari identifikasi faktor internal berupa kekuatan (strengths) dan kelemahan (weakness) yang berpengaruh terhadap Industri Rengginang. Penentuan nilai dan bobot dengan menggunakan metode paired comparison. Penentuan rating diperoleh dari dua orang responden dari beberapa pengusaha Industri Rengginang pemilik industri ini, sedangkan total skor dengan mengalikan bobot dan rating dapat adalah sebagai berikut : Berdasarkan hasil perhitungan dengan mengunakan matrik EFE diperoleh total skor yang dimiliki oleh Industri Rengginang sebesar 2,739. Skor bobot total yang berada di atas 2,5, mengindikasikan bahwa perusahaan mampu merespon dengan baik faktor eksternal dengan memanfaatkan peluang yang ada untuk mengatasi ancaman. Peluang utama yang dimiliki oleh perusahaan adalah tingginya loyalitas konsumen terhadap produk perusahaan (skor 0,261). Selama ini konsumen lebih merasa puas terhadap produk rengginang yang dihasilkan oleh Industri Rengginang ini dibandingkan dengan produk rengginang dari pesaing, karena memiliki kualitas dan rasa yang lebih baik serta harga yang terjangkau. Hal ini membuat para konsumen memiliki loyalitas yang tinggi dan cenderung menjadi 
pelanggan tetap serta menjadi media promosi bagi perusahaan melalui media mouth to mouth untuk menarik konsumen lain untuk membeli produk di perusahaan yang akan meningkatkan penjualan. Ancaman utama dari usaha Industri Rengginang adalah minimnya kegiatan produksi (skor 0,332). Sebagai sebuah perusahaan yang memproduksi produk berupa makanan, tentu harus banyak melakukan terobosan dalam bentuk promosi karena zaman terus berkembang dan sangat banyak sekali cara atau media untuk melakukan promosi. Dengan banyak melakukan promosi maka akan semakin bertamba pangsa pasar yang akan di kuasi oleh para pelaku rengginang bukan hanya sekedar mengandalkan promosi menggunakan mouth to mouth karena melakukan promosi banyak sekali yang bisa diraih oleh pengusaha rengginang.

\section{Perumusan dan Penetapan Alternatif Strategi Industri Rengginang}

1). Matrik IE (Internal-External), Berdasarkan hasil yang diperoleh dari matrik EFE dan matrik IFE maka dapat disusun selanjutnya dalam matrik Internal-Eksternal atau matrik IE. Matrik IE digunakan untuk menganalisis posisi perusahaan secara lebih detail dan melihat strategi apa yang tepat untuk diterapkan oleh perusahaan. Hasil dari penilaian matrik IE untuk Industri Rengginang dapat dilihat pada gambar 3.9. Nilai rata-rata IFE sebesar 2,392 dan rata-rata EFE sebesar 2,392 menunjukkan posisi Industri Rengginang berada pada sel V. Pada posisi ini strategi yang tepat untuk digunakan adalah strategi menjaga dan mempertahankan. Strategi yang dapat diterapkan oleh industri rengginang adalah strategi penetrasi pasar, pengembangan pasar dan produk.

2). Analisis SWOT, Alternatif strategi yang dihasilkan pada matrik IE adalah merupakan strategi umum yang tidak memiliki implementasi strategi yang lebih teknis pada tingkat perusahaan. Oleh karena itu matrik IE dilengkapi oleh matrik SWOT yang berupa langkah-langkah kongkrit yang dapat memberikan uraian lebih detail mengenai alternatif strategi yang sebaiknya dilakukan oleh perusahaan. 1). Strategi S-O (Strenghts-Opportunities), Strategi ini adalah untuk memanfaatkan seluruh kekuatan untuk merebut dan memanfaatkan peluang sebesar-besarnya. Strategi yang dapat digunakan yaitu pertama, mempertahankan harga yang selama ini telah ditetapkan kepada konsumen dengan tetap selalu 
meningkatkan kualitas produk untuk meningkatkan dan menjaga kepuasan dan loyalitas konsumen. Kedua, menjalin kerjasama dengan agen distributor yang potensial untuk memperluas wilayah pemasaran atau pendistribusian produk, sehingga akan menambah pangsa pasar. Ketiga, memanfaatkan lokasi yang strategis untuk mempermudah kegiatan pemasaran, pendistribusian, dan promosi produk untuk menarik pelanggan yang potensial, mengingat masih luasnya pangsa pasar yang ada. 2). Strategi S-T (Strenghts-Treathts), Strategi ini adalah untuk menggunakan kekuatan yang dimiliki perusahaan untuk mengatasi ancaman. Strategi yang dapat digunakan yaitu dengan menciptakan suatu inovasi produk yang baru dengan menciptakan suatu kreasi bentuk dan cita rasa baru untuk menambah konsumen baru sehingga dapat meningkatkan produksi dan penjualan produk. 3). Strategi W-O (Weaknesses-Opportunities), Strategi ini diterapkan berdasakan pemanfaatan peluang yang ada dengan cara meminimalkan kelemahan yang ada. Strategi yang dapat digunakan yaitu menjalankan sistem manajemen organisasi perusahaan untuk mempermudah dalam perencanaan, pengorganisasian, dan pengontrolan kegiatan operasional perusahaan yang sangat berpengaruh terhadap perkembangan perusahaan dan perkembangan dunia usaha yang semakin modern. Selain itu membangun atau menyewa sebuah kios di tempat-tempat yang strategis seperti di pinggir jalan raya utama kota dan ditempat-tempat wisata tertu perlu dilakukan untuk mempermudah melakukan promosi, dan pendistribusian produk dalam rangka meningkatkan penjualan dan memperluas wilayah pemasaran. 4). Strategi W-T (Weaknesses- Treathts), Strategi ini didasarkan pada kegiatan perusahaan yang bersifat defensif dan berusaha meminimalkan kelemahan yang ada serta menghindari ancaman. Strategi yang dapat dilakukan yaitu pertama, meningkatkan kegiatan promosi dengan metode yang lebih efektif dan efisien seperti brosur, spanduk, atau papan reklame untuk lebih memperkenalkan produk yang dihasilkan kepada masyakat untuk menarik pelanggan yang potensial dan memperluas daerah pemasaran serta mningkatkan volume penjualan. Kedua, membangun dan mengembangkan usaha patungan (Joint Venture) dengan pihak yang menyediakan modal dan bahan baku untuk meningkatkan kapasitas produksi, memenuhi kebutuhan modal yang masih 
minim, terutama untuk penambahan sarana dan prasarana serta riset dan pengembangan produk.

3). QSPM (Quantitative Strategic Planning Matrix), Tahap terakhir dalam perumusan alternatif strategi setelah sebelumnya memilih beberapa alternatif strategi adalah yaitu melakukan pengambilan keputusan untuk memilih strategi apa yang paling tepat untuk digunakan oleh perusahaan yaitu dengan menggunakan matrik Quantitative Strategic Planning Matrix (QSPM) yaitu untuk meringkas dan mengevaluasi berbagai alternatif strategi secara objektif berdasarkan faktor internal dan eksternal perusahaan yang sudah diidentifikasi sebelumnya. QSPM diperoleh dari hasil perhitungan dengan mengalikan rata-rata bobot dari masing-masing identifikasi lingkungan internal dan eksternal perusahaan dengan nilai daya tarik (AS) maka akan diperoleh nilai total daya tarik. berdasarkan hasil perhitungan TAS, yaitu: mempertahankan harga dan meningkatkan kualitas produk untuk meningkatkan kepuasan dan loyalitas konsumen dengan skor TAS sebesar 6,485. Alternatif strategi yang paling tidak diminati yaitu menjalankan sistem manajemen organisasi internal perusahaan dengan skor TAS sebesar 4,777.

\section{KESIMPULAN}

Berdasarkan hasil penelitian yang telah dilakukan maka dapat disimpulkan sebagai berikut: 1). Berdasarkan hasil wawancara yang dilakukan terhadap pemilik perusahaan Industri Rengginang di Kecamatan Sakra Pusat, startegi pemasaran yang dilakukan saat ini dalam memasarkan produk rengginangnya yaitu dengan masih dengan cara mouth to mout dan dengan cara konsumen datang langsung ke rumah pemilik untuk membeli rengginang. 2). Hasil dari analisis faktor internal perusahaan dengan menggunakan matrik IFE kekuatan utama perusahaan adalah produk yang berkualitas, sedangkan kelemahan utama yang dimiliki oleh para pengusaha Industri Rengginang adalah minimnya modal yang dimiliki. Total skor matrik IFE sebesar 2,392 dibawah skor bobot total 2,5, mengindikasikan bahwa lemahnya posisi internal perusahaan dalam mengatasi 
kelemahan yang ada dengan kekuatan yang dimilikinya. Hasil dari analisis matrik EFE yaitu Peluang utama yang dimiliki oleh perusahaan adalah tingginya loyalitas konsumen terhadap produk perusahaan. Ancaman utama dari perusahaan adalah banyaknya produk substitusi. Total skor matrik EFE diperoleh sebesar 2,739 di atas skor bobot total 2,5, mengindikasikan bahwa perusahaan mampu merespon dengan baik faktor eksternal dengan memanfaatkan peluang yang ada untuk mengatasi ancaman. Hasil dari penilaian matrik IE menunjukkan posisi perusahaan Industri Rengginang di Kecmatan Sakra Pusat pada sel V. Hasil analisis SWOT menghasilkan 8 alternatif strategi yang dapat dipilih oleh perusahaan yaitu: 1). Mempertahankan harga dan meningkatkan kualitas produk untuk meningkatkan kepuasan dan loyalitas konsumen. 2). Menjalin kerjasama dengan agen distributor yang potensial untuk menambah pangsa pasar. 3). Memanfaatkan lokasi yang strategis untuk menarik pelanggan yang potensial. 4). Menciptakan produk dengan bentuk dan cita rasa yang baru. 5). Mejalankan sistem manajemen organisasi internal perusahaan. 6). Membangun atau menyewa kios di tempat-tempat yang strategis untuk meningkatkan penjualan. 7). Melakukan kegiatan promosi dan iklan untuk menarik pelanggan potensial dan memperluas daerah pemasaran. 8). Membangun dan mengembangkan usaha patungan (Joint Venture) dengan pihak yang menyediakan modal dan bahan baku untuk meningkatkan kapasitas produksi. Berdasarkan hasil analisis matrik QSPM, dari delapan alternatif strategi yang ada terdapat satu alternatif strategi yang diprioritaskan untuk dilakukan oleh perusahaan yaitu mempertahankan harga dan meningkatkan kualitas produk untuk meningkatkan kepuasan dan loyalitas konsumen dengan skor TAS sebesar 6,485.

\section{DAFTAR RUJUKAN}

Arikunto, Suharsimi, 2006. "Prosedur Penelitian Suatu Pendekatan Teoristik". Rineka Cipta, Jakarta.

David, Fred, R. 2010. Strategic Management. Manajemen Strategis. Edisi Keduabelas, Buku Satu. Jakarta: Salemba Empat. 
Kotler, Philip dan Armstrong, Gary. 2008. Prinsip-prinsip pemasaran. Jilid 1. Edisi Keduabelas. Jakarta: Erlangga.

Kotler, Philip. 2005. According To Kotler: Dalam Menjawab Pemesaran. Jakarta. PT. Bhuana Ilmu Populer

K.Yin, Robert. 2011. Studi Kasus Desain dan Metode. Jakarta. PT. Raja Grafindo Persada.

Moleong, Lexy, J. 2006.” Metodologi Penelitian Kualitatif”. PT Rosda Karya, Bandung.

Mohammad Takdir Ilahi. 2010. Revitalisasi Potensi Ritel Makanan: Usaha Strategi Pemasaran Home Industry Rengginang di Madura. Diunduh di http://mohammadtakdirilahi.blogspot.com/2010/10/revitalisasi-potensi ritelmakanan_13.html Tanggal 15 April 2016.

Pasaribu, Leonard. 2008. "Analisis Strategi Pemasaran Susu UHT (Ultra High Temperature) (Studi Kasus : PT. ULTRAJAYA Tbk, Bandung)”. Tidak Dipublikasikan. Skripsi. Bogor. Institut Pertanian Bogor. Diunduh di http://repository.ipb.ac.id/bitstream/handle/123456789/2054/A08lpa.pdf? sequence=5 Tanggl 02 Maret 2016.

Purnama, Lingga, M.C. 2004. Strategi Marketing Plan. Jakarta: PT. Gramedia Pustaka Utama

Rangkuti, Freddy. 2001. Analisis SWOT "Teknik Membedah Kasus Bisnis". Jakarta: PT. Gramedia Pustaka Utama.

Rangkuti, Freddy. 2003. Busnis Plan : Teknik Membuat Perencanaan bisnis dan Analisis Kasus. Jakarta. Pt. Gramedia Pustaka Utama

Sugiyono. 2011. Metodologi Penelitian Kuantitatif, Kualitatif, R dan D. Alfabeta Bandung.

Supranto, J. 2003. Metode Riset Aplikasinya dalam Pemasaran. Jakarta: Rineka Cipta 